doi: http://dx.doi.org/10.7213/psicolargum.36.93.AO01

\title{
Mitos e representações sociais sobre altas habilidades/superdotação: revisão sistemática
}

\author{
Myths and social representations about high skills/giftedness: systematic review
}

Mitos y representaciones sociales sobre altas habilidades / superdotación: revisión sistemática

\author{
Francislaine Wiczneski Doi ${ }^{[a]}$ \\ ${ }^{\text {[a] }}$ Mestre em Psicologia pela Universidade Tuiuti do Paraná. Curitiba, Paraná, Brasil. \\ franwdoi@gmail.com
}

\begin{abstract}
Gislei Mocelin Polli ${ }^{[b]}$
${ }^{[b]}$ Doutora em Psicologia. Professora do Mestrado em Psicologia - Universidade Tuiuti do Paraná, Curitiba, Paraná, Brasil. gismocelin@gmail.com ORCID https://orcid.org/0000-0001-
\end{abstract} 7254-7441

\section{Adriano Valério dos Santos Azevêdo ${ }^{[c]}$ \\ ${ }^{[c]}$ Doutor em Psicologia}

Professor do mestrado em Psicologia - Universidade Tuiuti do Paraná, Curitiba, Paraná, Brasil. adrianoazevedopsi@yahoo.com ORCID https://orcid.org/0000-0003-0238-3423

\begin{abstract}
Resumo
Mitos e representações sociais (RS) sobre pessoas com Altas Habilidades / superdotação (AH/SD) influenciam as relações desenvolvidas entre os profissionais e as pessoas com esta condição. Esta revisão sistemática teve como objetivo realizar um levantamento da literatura científica para verificar como os mitos e RS sobre AH/SD tem sido investigados. Para tanto foram pesquisados artigos em inglês, português e espanhol nas bases de dados Scielo, Pepsic, BVS-Psi, PubMed, e Redalyc. Foram incluídos artigos empíricos que abordassem o tema "mitos sobre AH/SD" ou "RS sobre AH/SD" como tema principal. Os resultados mostraram poucos estudos brasileiros recentes sobre o assunto, além disso, foram identificados diferentes conceitos para verificar o que as pessoas pensam sobre $\mathrm{AH} / \mathrm{SD}$, tais como: percepções, mitos, equívocos, representações sociais, entre outros. A análise dos artigos permitiu concluir pela necessidade de uniformidade em conceitos e teorias, bem como a necessidade de realizar mais pesquisas sobre o assunto.
\end{abstract}

Palavras-chave: representações sociais; mitos; altas habilidades; superdotação

\begin{abstract}
Myths and social representations (SR) about highly skilled/giftedness (HS/GD) influence the relationships developed between professionals and people with this condition. This systematic review aimed to conduct a survey on the scientific to check how the myths and SR about HS/GD have been investigated. For that, articles in English, Portuguese and Spanish were searched in the databases Scielo, Pepsic, BVS-Psi, PubMed, and Redalyc. Empirical articles were included that addressed the theme "myths about HS/GD" or "RS about HS/GD" as the main theme. The results showed few recent Brazilian studies on the subject, besides that, it has been identified different concepts to verify what people think about HS/GD, such as: perceptions, myths, misconceptions, social representations, among others. The analysis of the articles allowed us to conclude for the need of uniformity in concepts and theories, well as more research on the subject.
\end{abstract}

Keywords: social representations; myths; high abilities; giftedness 


\section{Resumen}

Mitos y representaciones sociales sobre personas con Altas Habilidades / superdotación (AH / $\mathrm{SD}$ ) influencian las relaciones desarrolladas entre estas personas y los profesionales. Esta revisión sistemática tuvo como objetivo realizar un levantamiento de la literatura científica para verificar cómo los mitos y RS sobre AH / SD han sido investigados. Por lo tanto, investigamos artículos en inglés, portugués y español en bases de datos Scielo, Pepsic, BVS-Psi, PubMed y Redalyc. Se incluyeron artículos empíricos que abordaran el tema "mitos sobre AH / SD" o "RS sobre AH / SD" como tema principal. Los resultados mostraron pocos estudios, además, se identificaron diferentes conceptos para verificar lo que la gente piensa sobre AH / SD, tales como: percepciones, mitos, equívocos, representaciones sociales, entre otros. El análisis de los artículos permitió concluir por la necesidad de uniformidad en conceptos y teorías, así como la necesidad de realizar más investigaciones sobre el tema.

Palabras clave: representaciones sociales; mitos; altas habilidades; superdotación

\section{Introduction}

The estimate of people with high skills/giftedness (HS/GD) is $3.5 \%$ to $5 \%$ of the world population and these numbers are based on IQ tests, which are not considered conclusive for the diagnosis. Thus, it is possible that the number of people with HS/GD worldwide is higher than estimated (WHO, 2002). In Brazil, considering that estimate, we get close to nine million people with HS/GD. These numbers justify the growing interest of researchers in Brazil and abroad about the HS/GD subject (Sabatella, 2013).

With regard to what is understood as giftedness or high skills, there are myths that generate stereotypes that hinder these people, it makes difficult the effective and welcoming service for this population (Pérez, 2011). As stated in the teacher's orientation booklet of the Ministry of Education, the dominant thinking when talking about HS/GD is that these people are considered geniuses, who dominate all knowledge, have exemplary behaviors, among other suggestive ideas present in the imaginary of society. These misconceptions are shared intergenerational way and they damage the academic and social development of people with HS/GD (Brasil, 2007).

Surveys conducted in Brazil (Alencar \& Fleith, 2001; Antipoff \& Campos, 2010; Rech \& Freitas, 2005; Sabatella, 2013) investigated the secular conceptions that underlie the theme of HS/GD, their effects and the need to clarify them for an effective action in behalf of these people. Antipoff and Campos (2010) warn on the urgency of more concrete actions aimed to raise awareness to demystify such conceptions, thus helping 
people with HS/GD to have their educational needs really addressed. These conceptions are called by some authors as myths, by others, they are called beliefs, perceptions, among other adopted nomenclatures (Sabatella, 2013). Abroad, researchers are dedicated to the same subject, also using several terms to perceive what people think about HS/GD (Kaya, Ogurlu, Tasdemir \& Toprak, 2015; Tavani, Zenasni \& Pereira-Fradin, 2009).

The Theory of Social Representations (TSR) can help in understanding the myths about HS/GD disseminated in our society. According to Jodelet (2001) Social representations (SR) are knowledge shared by people who communicate. This knowledge creates a socially shared reality. The SR may correspond to true knowledge, but they can, to the same extent, be completely false, since they originate in social discourse and are passed on informally. They are influenced by scientific knowledge, but they do not correspond to this knowledge, being a day-to-day knowledge, a commonsense knowledge.

Social Representations (SR) serve to justify practices, they make up a knowledge that can guide behaviors and form identities (Polli et al., 2018). Moscovici (1982) highlights the daily nature of the construction of social representations. The founder of the Theory of Social Representations compares the SR in our society to the myths and belief systems of traditional societies. Polli and Camargo (2015) indicate that we form SR about objects that are relevant, all themes that are discussed in social groups or diffused by the far-reaching media. SR on HS/GD can be included in this universe of consensual knowledge. The SRs refer to shared thinking about HS/GD without distinction between right or wrong. In studies on the subject, myths are understood as misconceptions about this phenomenon, which are called in this article by myths / SR.

Winner (1996) devoted his studies to the so called myths that permeate the HS/GD, which include: global giftedness, which states that the gifted ones will have high performance in all academic areas; talented, but not gifted ones who believes that every child will have HS/GD in some area; exceptional Intelligence coefficient (IQ), all the giftedness ones have a very high IQ; biology versus the environment, which states that genetics is determinant; guiding parent, regarding the affirmation that children with HS/GD are the result of the parents' encouragement; people with HS/GD have excessive psychological health; all children are gifted; and children with HS/GD become eminent adults. 
The scientific conceptualization for HS/GD is not considered simple, but dynamic and complex because it deals with many involved skills, besides currently it aims to include factors such as: curiosity, leadership, creativity, specific talent and interest far superior than the aged group (Sabatella, 2013). However, the definition of the HS/GD term also involves a lack of consensus caused by a variety of theories developed in an attempt to explain the phenomenon of HS/SR and yet to be a socially constructed concept (Azevedo \& Mettrau, 2010). It is difficult for anyone conducting international research in databases, since concepts are broad and overlapping. With this scenario in view, the term applied in this article - HS/GD - is the integration of the term defined by the European Council - High Abilities (HA) - adding the term of the World Council - SR; this is the terminology most applied in Brazil.

In order to a person be considered with $\mathrm{HS} / \mathrm{GD}$, he/she must present a high performance, compared to the same age group. In addition, the person needs for mastery in one or more of the following areas: psychomotor skills, academic ability in some specific content, general scholar's ability, creative-productive, visual and/or practical arts (Brasil, 1995). Therefore, this definition is supported by the theory of the "three rings conception" by Renzulli (1986), which adds the factors: creativity, engagement with the task/motivation, and specific or general ability above the average. Thus, people with HS/GD necessarily have these three characteristics, but to a greater or lesser extent.

A review study was conducted in Brazil with the objective of knowing the Brazilian scientific publications on HS/GD in the Scielo and Pepsic databases. As a result, 19 empirical and theoretical articles were found between 2002 and 2009 that dealt with themes such as: conceptual definitions, theoretical models, identification of this population, enrichment/care programs, public policies, research with teachers and family members, social emotional dimension, behavioral and emotional changes (Nakano \& Siqueira, 2012). A study aimed to identify the productions of the Brazilian literature on the subject between the years of 2011 and 2015 with the objective of monitoring the advances on HS / DG. the authors identified 52 productions dealing with themes such as Policies Public and Inclusion, Teacher Education and Practice, Characteristics and Identification, Skills Development, Literature Review, Terminology and Testing (Pederro et al., 2017).

Another study was carried out to identify and analyze dissertations and theses on HS/GD in Brazil. The following thematic categories were identified: identification and 
characterization of people with $\mathrm{HS} / \mathrm{GD}$, specialized care programs, perceptions and opinions of people about HS/GD, document analysis and bibliographic research, teaching practices and methodologies, desirable characteristics in teachers, inclusion in mainstream education, the learning process, the family of this population, adults with HS/GD, bullying, morbidities in HS/GD, precocity, and the play in HS/GD. The results of this research have indicated that the predominant theme is in the educational area and that there is a growing trend for researching on this topic. Besides that, there is no uniformity regarding the scientific production on HS/GD in the regions of Brazil, in other words, the Southeastern region of Brazil is the one that produces more knowledge in this area while other regions do not produce or produce far less (Chacon \& Martins, 2014). It is observed that these reviews are HS/GD overviews on the subject without the purpose of search specifically for scientific work produced in the field of myths / SR on HS/GD. In a similar study, Martins, Pedro and Ogeda (2016) identified the prevalence of studies addressing the identification of students with HS/GD.

A survey conducted with 269 children with HS/GD aimed to investigate the relationship between social skills and subjective well-being, a theme that is not well researched. The results have shown that, the more developed social skills these children have, the higher is the subjective well-being level. Another interesting finding is that children who shown more assertiveness skills, have also shown higher levels of positive affection and subjective well-being (França-Freitas, Prette \& Prette, 2017). These results confirm the fact that these people need a welcoming and skillfully attitude from professionals for an effective care for their families and professionals.

Considering the scientific necessity of deepening the theme, due to the existence of few studies made in this area, the main objective of this study arises: conduct a survey of scientific literature to see how the myths and SR about HS/GD have been investigated.

\section{Method}

This research is a systematic review of scientific literature that provides an analysis of the scientific production in a given subject, in a period of time, providing an overview of the study area. This study followed Preferred Reporting Items for Systematic Reviews and Meta-Analyses (PRISMA) procedures and recommendations. In this context, the most used keywords were defined in the following languages: Portuguese-Brazil, English, 
Spanish and Portuguese-Portugal. To obtain the key words in other languages was not only necessary to translate the keywords, but also the verification of scientific terms used for in each country, since there is no global consensus on the terms used to HS/GD. Thus, the keywords set are - Portuguese - Brazil: mitos, representações sociais (RS), altas habilidades, dotado, talento, superdotado, superdotação e dotação. English: myths, social representation (SR), highly skilled, talented, super-giftedness, giftedness and gifted. Spanish: mitos, representaciones sociales (RS), altas capacidades, superdotado e superdotación. Portuguese - Portugual: mitos, representações sociais (RS), sobredotado e sobredotação. Consequently, it was determined that the search in databases would carry out to each keyword defined for HS/GD along with the word myth or social representations, separated by the descriptors AND and OR, for example: highly skilled AND myths OR social representations.

The literature research took place between the months of May and July, 2017 in the following databases: Scielo, Pepsic, BVS Psi, PubMed, Redalyc and scholar Google. Empirical articles were included that addressed the theme "myths about HS/GD" or "SR about HS/GD" as the main theme. The documents in articles format that returned in the results were taken into consideration, as there were no pre-established deadlines regarding the year of publication. Thus, articles between the years 2005 till 2017, corresponding to the first and last date of publication, were considered as they present the inclusion criteria.

The exclusion criteria were as follows: articles that do not contain the searched subject, duplicated articles in different databases, as well as theses, dissertations and books. Reading the title, followed by the abstract reading, made the refinement possible. This evaluation was done independently by two judges, who agreed with the articles that composed this systematic review.

\section{Results}

The electronic searches allowed the location of 51 articles by reading the title and the abstract, however, it was found that 34 of these were repeated and seven ones did not address the subject, this way, they were excluded. 10 potentially relevant articles remained, which were published between 2005 and 2017. Three of them were published in 2014. The information flow with the different phases of the systematic review can be observed in Figure 1. 


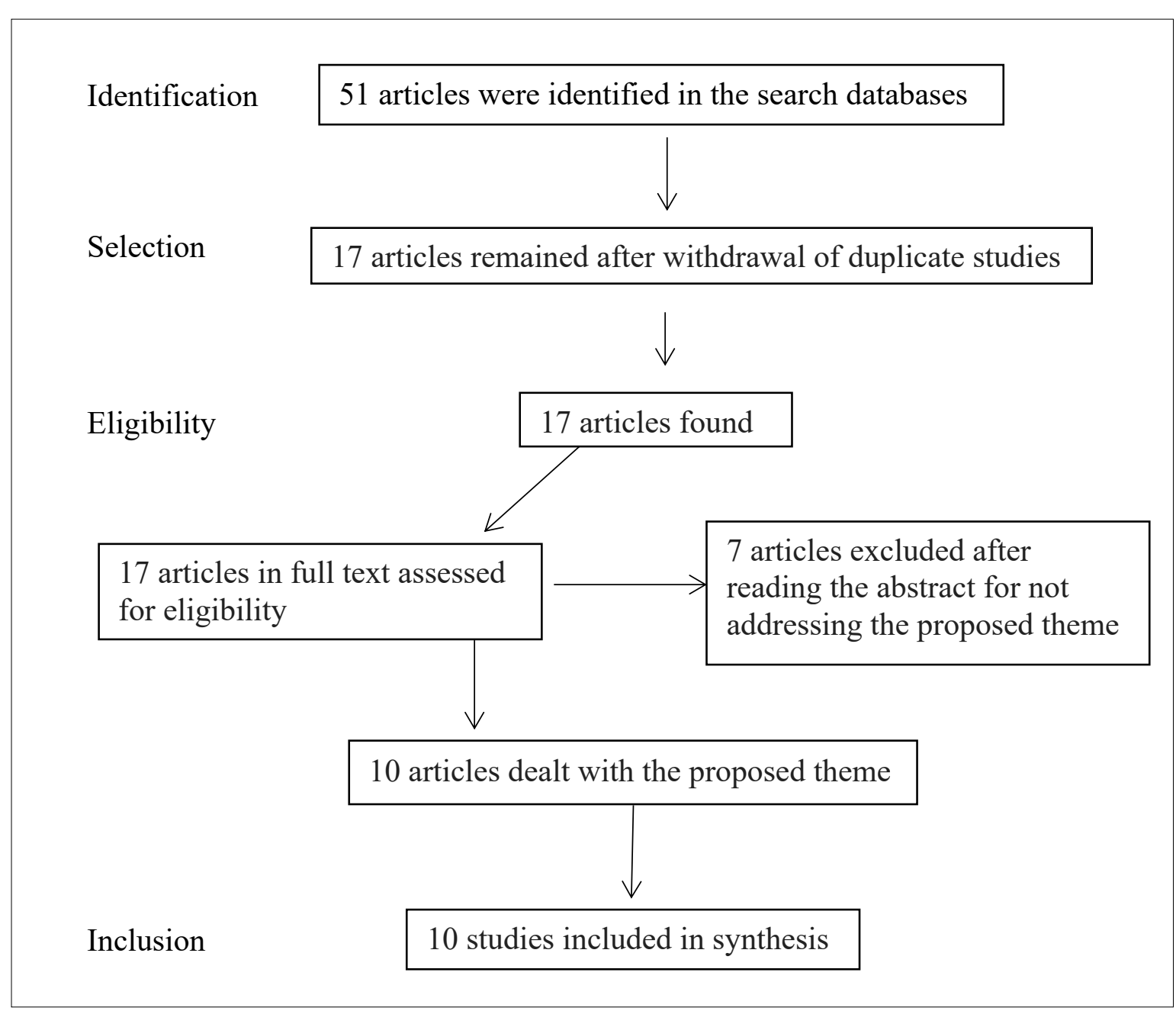

Figure 1. Flowchart of the search process and selection of articles

From the found articles, seven were produced and published in Brazil, one in France, one in England and one in Turkey. Only teachers have participated in the following articles: one, four, six and eight. Teachers and school staff participated in the study number five, in study number two, seven and ten participated students from the University and for the study number three and nine people from the general population have participated. The studies analyzed can be observed in Table 1.

Table 1.

Main characteristics of studies on myths/SR in HS/GD.

\begin{tabular}{|c|c|c|c|}
\hline Article title & Authors & Year & $\begin{array}{l}\text { Number of } \\
\text { Participants }\end{array}$ \\
\hline $\begin{array}{l}\text { Uma análise dos mitos que } \\
\text { envolvem os alunos com altas } \\
\text { habilidades: a realidade de uma } \\
\text { escola de Santa Maria/RS. }\end{array}$ & $\begin{array}{l}\text { Rech \& } \\
\text { Freitas }\end{array}$ & 2005 & 10 \\
\hline $\begin{array}{l}\text { Perceptions of developmental, } \\
\text { social, and emotional issues in } \\
\text { giftedness: Are they realistic? }\end{array}$ & $\begin{array}{l}\text { Bain, Bliss \& } \\
\text { Choate }\end{array}$ & 2006 & 285 \\
\hline
\end{tabular}


Social representation of gifted children: A preliminary study in France.

Altas habilidades/ superdotação: mitos e dilemas docentes na indicação para o atendimento. Altas habilidades e o desafio do atendimento.

Altas habilidades/ superdotação no contexto escolar: percepções de professores e prática docente.

A carência de formação sobre a superdotação nas licenciaturas da UFPEL: um estudo de caso.

A percepção dos coordenadores de licenciaturas da UEL sobre altas habilidades/ superdotação.

Social representation of giftedness in Turkey

Percepção de professores em cursos de formação sobre talentos/ superdotação
Tavani,

2009116

Zenasni \&

Pereira-Fradin

Azevedo \&

$2010 \quad 52$

Mettrau

Barreto \&

Mettrau

$201036+$ not

informed

Bahiense \&

$2014 \quad 20$

Rossetti

Ramalho,

$2014 \quad 94$

Silveira, Barros \&

Brum

Cianca \&

$2014 \quad 14$

Marquezine

Kaya, Ogurlu,

$2015 \quad 523$

Tasdemir \&

Toprak

Wechsler \&

$2016 \quad 170$

Suarez

With regards to the method used in the studies, there were more descriptive studies with cross-sectional design, three studies are qualitative (Bahiense \& Rossetti, 2014; Barreto \& Mettrau, 2010; Rech \& Freitas, 2005) and seven studies have a countyqualitative approach (Azevedo \& Mettrau, 2010; Bain, Choate \& Bliss, 2006; Cianca \& Marquezine, 2014; Kaya et al., 2015; Ramalho, Silveira, Barros \& Brum, 2014; Tavani et al., 2009; Wechsler \& Suarez, 2016).

Rech and Freitas (2005) sought to investigate myths present in teachers' reports. Nine teachers had participated in training on HS/GD, and one of the teachers did not participate in that training. The researcher's used the pre-defined categories of myths by Pérez (2011), which are about: constitution, distribution/incidence, identification, levels or degrees of intelligence, performance, consequences and attendance. The myth most mentioned by those teachers was "that HS/GD is an exclusively genetic trait" and this myth was presented in the reports of five teachers, that is, half of the teachers mentioned this myth. While the myth that says HS/GD is a characteristic that depends exclusively 
on environmental stimulus was not mentioned by any teacher. Another interesting fact found in this study is that the only teacher who did not participate in HS/GD training voiced the presence of five of the nine myths mentioned by the authors. Other teachers mentioned an average of two of the myths. The authors emphasize the urgency of including the theme HS/GD in under graduation courses and the continuous training for teachers and staff in schools. Since the number of students with HS/GD is much higher than it is believed as a common sense, the need for professionals well-prepared to assist this population, that needs special education, as much as the students with any kind of disability.

Bain, Bliss, and Choate (2006) investigated in England the perceptions about HS/GD of 285 university students in courses on human development and educational psychology. A questionnaire with 50 questions was applied to investigate demographic questions, such as development and family environment; social and emotional behavior; and the interviewee's expectations about future achievements. The results showed that $63 \%$ of the participants agree that children with HS/GD will be more advanced in certain areas, $72 \%$ said that children with HS/GD form a homogeneous group regarding their characteristics, $79 \%$ believe that siblings of children with HS/GD suffer from stress to live with them, 59\% said that there are efforts to stimulate early children's development, $60 \%$ believe this population suffers more emotional problems than the general population, $77 \%$ reported that children with HS/GD are more prone to social problems and $90 \%$ believe that these children are less likely to drop out school. The authors pointed out that students identified themselves with HS/GD were less likely to correlate HS/GD with dropout and delinquency. In three of the topics investigated the perceptions are different from what is presented in the scientific literature, they are: children with HS/GD are emotionally vulnerable, they have problems in social relationships and their siblings, who do not have HS/GD, tend to suffer from stress.

To investigate SR on HS/GD in France, researchers Tavani et al. (2009) interviewed 116 adults, divided them into two groups. One group had 75 participants related with people with HS/GD and the other one had 41 participants who had no contact with people with HS/GD. For this research they used the method of free association, in which participants provide five characteristics that come to their minds in relation to children and adolescents with HS/GD. The other instrument used was the similarity analysis, which applied the rate of co-occurrence of evocations among the participants. The results 
indicated that people who have contact with children/ adolescents with HS/GD presented SR organized around the expressions: sensitive, curious and intelligent. While the group that does not have contact with children/adolescents with HS/GD demonstrated as the main SR only the word: intelligent. That is, the group that has contact evoked both functional elements - sensitive and curious - as well as normative - intelligence. The noncontact group evoked only the normative element - intelligence. The authors point out that these results suggest the possibility that the intelligence is a stereotyped response for both groups. The researchers concluded that the group that had contact with this population had SR closer to scientific literature than the group that had no contact. They highlighted the importance of emphasizing the SR on HS/GD to change the attitude and opinion relating the unhelpful stereotypes associated with this population.

The study by Azevedo and Mettrau (2010) aimed to identify the difficulties that pass through the myths in the indication of students with HS/GD for a specialized assistance by 52 teachers. They used instruments in order to investigate the sociodemographic profile of the respondents, the evocation of up to three words in front of the two inductive terms - people with HS/GD and special education - and the dilemmas of these teachers based on the theory of moral judgment related to the myths. Participants were divided into two groups of 26 participants each, and in group one the teachers had indicated students with HS/GD for specialized assistance and in group two there were no indications. Although the two groups participated in training on the HS/GD theme prior to the survey, the authors found out that group one evoked more words found in the literature than group two. The number of teachers with higher education between these two groups were respectively 14 and 24 . In other words, the group one had fewer participants with a higher degree, and even so they demonstrated to have less influence of myths in their responses than the group two. The myth that most appeared among teachers was "that people with HS/GD are academically superior and always achieve excellent results". The myth that these students do not need a special attendance also appeared in the answers, such attendance is presented by the participants as something only for students with disabilities. The need to know the public policies on HS/GD also appeared in the reports. Teachers answered that they believe in the existence of students with HS/GD in all schools, but the amount of indication of these students for specialized attendance is low. This low index, together with the fact that this research was carried out in the periphery of Rio de Janeiro, motivated the reflection on the need to clarify that 
there are students with HS/GD in all schools, regardless of social class, ethnicity, locality, etc. The authors pointed out that, in both groups, it was verified the presence of myths and that they interfere with the performance of the teachers. Also, there is a real need to investigate, not only the legal and theoretical aspects, but also the myths that permeate every indication/no indication of students with HS/GD, so that they are not going to be harmed.

Barreto and Mettrau (2010) investigated SR on HS/GD and the presence of indications of these students for attendance. Before conducting the research in this school, a lecture on HS/GD was carried out aiming at favoring the formation of SR in teachers, since these SRs are socially constructed, and in this case HS/GD, SRs are closely related to everyday teacher's practice. The researchers worked with two groups of participants, one composed of 36 teachers and the other composed of staff from different school sectors. The teachers stated that the information they had about HS/GD came from informal and formal sources, including television media, the internet, pedagogic meetings, among others; showing a superficial knowledge about the subject. However, 27 teachers said that they had noticed some students with HS/GD during their careers; 23 were aware of the existence of public policies for this population; 32 recognized that it is the teacher's role to identify and attend these students; 24 believe it is possible to implement programs for students with HS/GD, but 27 participants considered this implementation as a responsibility of the special education sector. Respondents from different school sectors declared unanimously that there was no confirmed case of the existence of HS/GD students at that school, only suspicions that had not been consisted investigated. In this research, the presence of SRs corresponded to the myths found in the literature on HS/GD, by teachers and school staff. Although the respondents stated that there were no students with HS/GD at that school, the researchers noticed evidence of the presence of these students in the student body and, due to the influence of SR in the professional performance, those students remained unassisted. The authors emphasize that this is a reality that has been identified in the literature for some time, but that this practice with the HS/GD students still lingers. There is a need for a more effective under graduation qualification, and this qualification needs to last during everyday school practice.

Aiming to analyze the conceptions of 20 teachers about HS/GD and their relationships with the teaching practice, Bahiense and Rossetti (2014) developed a survey 
with elementary school teachers in a public school. The results pointed out that respondents believe that students with HS/GD need specialized attendance and teachers do not receive adequate academic training to deal effectively with those students. It was found that 15 teachers think that the genetic factor is important, but not decisive to define a person with HS/GD and also the same number of teachers say these students do not need to master all the content presented in the classroom. It was identified that 12 participants believe that students with HS/GD suffer exclusion and isolation in the classroom. The authors emphasize that, as the HS/GD phenomenon is socially constructed, so are the myths. Therefore, it becomes important to identify the influence of myths in social practices in order to avoid interfering negatively in relationships. Another point highlighted by the authors is that, as such action happens at school, teachers need training on the subject during and after their graduation courses.

Ramalho, et al. (2014) developed a study with 94 undergraduate students in mathematics to know their conceptions about HS/GD. The study demonstrated that 87 participants had never studied anything about HS/GD and six students, who claimed to know something about the subject, declared they had acquired such knowledge in reports and other informal sources. Regarding the myth that the student with HS/GD performs well in all subjects, 56 participants responded positively to this question. The stereotype that the math student has higher chances of having HS/GD appeared in the results and was commented by the authors as a worrying factor. When participants were asked if they had HS/GD, 71 responded no and 11 responded perhaps. However, when they were asked if they were talented in mathematics, 27 responded yes and 43 responded perhaps. It was evident the presence of the myth that the HS/GD phenomenon is rare, even the respondents did not identify themselves with the profile discussed. Another highlighted myth in this research was the genetic factor as a determining characteristic of HS/GD, therefore, 66 respondents responded positively to this question. It was also noticed that 80 participants were not aware about the existence of public policies that support people with HS/GD, 56 participants believed that people with HS/GD have a guaranteed professional future and 66 supported a special education for HS/GD students. The research showed the lack of knowledge about the topic by the college students as well as the influence of the myths in the participant's conceptions about HS/GD.

To identify the perception of 14 teachers, coordinators of undergraduate courses at the State University of Londrina (UEL) on HS/GD, the researchers Cianca and 
Marquezine (2014) interviewed them and they used the Content Analysis to investigate the transcribed reports, in addition to the QDA Miner software that encoded the text data for tables and statistics. The results showed that 13 teachers believed that the incidence of students with HS/GD is low, that is, it is rare; seven of them claim to have lacked knowledge about the subject; five reported that the gifted is that student who learns everything by himself / herself and who strives for it; and eight teachers believed that this population has skills in specific areas. The researchers concluded that it was possible to verify that the survey participants had knowledge about the subject based on common sense, and not the scientific literature produced on HS/GD and they suggest the necessity for more research in the area.

A survey was held in Turkey with 523 participants to investigate the SR on HS/GD, in which the respondents were divided into two groups. One with 117 people who had received some sort of training on HS/GD compared to the other 416 people who had not received such training. It was used a questionnaire with demographic questions and a question which should be answered with five different words about HS/GD. The data were analyzed using the word association method, in which the frequency and order of the words were evaluated. The results showed the key elements in the group that received training were: smart, different and creative. Peripheral elements were: skill, curious, experienced, hyperactive, researcher and solitary. This group reported 18 positive words and only 3 negative ones. In the group that received no training, the core elements were: smart, successful and skilled. In addition, as peripheral elements of this group appeared: imagination, questioner, thinker, good understanding, abnormal, high intelligence, honesty, well cared and special education. The researchers found in this study that the positive words concerning to HS/GD appeared more often than negative words, in both groups. It was identified that to have knowledge of the HS/GD theme contributes to the construction of SR that soften negative stereotypes, favoring population HS/GD (Kaya et al., 2015).

Muglia Wechsler and Suarez (2016) conducted a survey with 170 college students in the final year of their under-graduation courses in order to investigate whether these students were prepared to deal with students with HS/GD. For this survey a questionnaire was used with open questions, which were categorized by content analysis and therefore the data were submitted to descriptive statistics. The most significant results were: $97 \%$ of respondents intended to work as teachers; $40 \%$ believed that people with HS/GD born 
with talent but may also have developed the skills along their growth $55 \%$ stated that the notion about HS/GD is the skill or ability to learn. The strategy mentioned by $70 \%$ of respondents as the best way to assist the students with HS/GD was implementation of specific programs for the skills development with the help of experts; $46 \%$ of respondents said that any kind of content, regarding to dealing with HS/GD students, was offered during the graduation course, $85 \%$ of the students pointed that competes the school to identify, develop and direct talented students to attractive and efficient strategies of learning. The researchers found that these future teachers, who participated in the survey, have considerable doubts about the concept of the phenomena talent and giftedness, in addition they are not prepared to identify and assist these students.

\section{Discussion}

It was observed that 10 scientific studies investigated the existence of myths/SR, their influence in the academic practices and the lack of professionals well prepared to deal with people with HS/GD (Azevedo \& Mettrau, 2010; Bahiense \& Rossetti, 2014; Bain et al., 2006; Barreto \& Mettrau, 2010; Cianca \& Marquezine, 2014; Kaya et al., 2015; Ramalho et al., 2014; Rech \& Freitas, 2005; Tavani et al., 2009; Wechsler \& Suarez, 2016). This unanimity is in line with the objective of studies in establishing the presence and negative influence of the myths/SR in HS/GD phenomenon of people who are unaware of the issue, contributing on a large scale for the social exclusion of this population.

These studies considered related issues to the need for formation during and after the under-graduation these issues are discussed by the authors with a sense of urgency due to the severity of the negative effects that this uninformed practice can generate (Bahiense \& Rossetti, 2014; C. M. F. Barreto \& Mettrau, 2010; Rech \& Freitas, 2005; Wechsler \& Suarez, 2016). As stated by García-Barrera and Bloom (2016) that the initial and ongoing training of teachers on HS/GD will result, not only in advancing the identification and appropriate assistance, but also results in combating stereotypes that accompany students with HS/GD.

The public policies that guarantee the rights of people with HS/GD, is a familiar topic, as it became evident in the studies by Azevedo and Mettrau (2010), Barreto and Mettrau (2010), Ramalho, et al. (2014). However, it is not enough knowing about the 
existence of public policies, the professionals from this field need to know thoroughly the topic HS/GD and the legislation that supports these people. According to Delou (2007) Brazil has policies that recognize the singularities of all HS/GD phenomenon and this is considered as a legislators' breakthrough, who have stepped forward to educators who still resist to deepen into the theme. Wechsler and Suarez (2016) claim that, although there are laws that support students with HS/GD, teachers are not prepared to put into practice such laws.

Barreto and Mettrau (2010), Bahiense and Rossetti (2014), Ramalho et al. (2014) found out that the myths / SR in teachers' thinking and daily practices cause exclusion of people with HS/GD. Already, Barreto and Mettrau (2010) argue that this population have their rights denied, as in any group there is an estimated incidence of $1 \%$ to $10 \%$ of people with HS/GD. The exclusion of people with HS/GD is a phenomenon considered cruel and obscure, simply because the ignorance on the subject fosters the marginalization of this population (Sabatella, 2013). To devalue the other find in the common sense justification for such situations. The power relations emphasize beliefs and representations of individuals who have experienced exclusion (Jodelet, 2001).

The main myths/SR presented in the studies were related to: 1. homogeneity perceptions among people with HS/GD; 2. asymmetrical development between cognitive and emotional; 3. Genetic factor versus environment as determinant; 4 . the rarity of the phenomenon, suggesting these people do not need support to learn, among others are discussed in the literature on HS/GD (Alencar \& Fleith, 2001; Pérez, 2011; Winner, 1996). Such myths/SR corresponding to the categories of myths developed by Pérez (2011) that are: subject constitution, distribution or incidence, identification, performance, consequences and attendance.

Out of the nine myths/SR investigated by Rech and Freitas (2005) the one presented in half of the participants' speech is the myth that HS/GD is an entirely genetic trait. Distinctly, the result in Bahiense and Rossetti's research (2014) shows that 15 of the 20 teachers reported that genetics is an important factor, but not a determining one whether people present HS/GD or not. Although the results presented in these two studies should not be considered with the intention of generalization, this apparent inconsistency in the results is just one example that comes to reaffirm the lack of scientific knowledge about HS/GD and among education professionals. 
It's no wonder that in all 10 selected studies, there were researches on what people think about HS/GD, although different terms were used. The more predominant terms in the studies were: myths and perceptions (Cianca \& Marquezine, 2014), myths and SR (Azevedo \& Mettrau, 2010) myths and conceptions (Bahiense \& Rossetti, 2014), as SR (Barreto \& Mettrau, 2010; Kaya et al., 2015; Tavani et al., 2009), as perceptions (Bain, et al., 2006; Wechsler \& Suarez, 2016) or just myths (Ramalho et al., 2014; Rech \& Freitas, 2005). This lack of consensus and uniformity in the scientific literature on myths/SR, which resemble the much discussed lack of consensus within the general area of HS/GD, affect the population HS/GD that is already considered invisible. Güçyeter, Kanl1, Özyaprak e Leana-Taşcılar (2017) claim that one of the most important action that needs to occur for benefitting people with HS/GD is to eliminate the inconsistency between theoretical definitions and their impacts on daily practices. Researchers should be based on the social-cultural context of each country, considering the dynamic and multifaceted nature of the HS/GD phenomenon.

It was possible to observe that eight of the 10 empirical studies that investigated the myths/SR were held in the school environment, whether in schools or universities (Azevedo \& Mettrau, 2010; Bahiense \& Rossetti, 2014; Bain et al., 2006; Barreto \& Mettrau, 2010; Cianca \& Marquezine, 2014; Ramalho et al., 2014; Rech \& Freitas, 2005). This practice is understood as effective, as the school environment is conducive to a systematic, prolonged and qualitative observation of the terms of skills, performance and capacity (MEC, 2006, p.20). The fact that five studies have teachers as participants (Azevedo \& Mettrau, 2010; Bahiense \& Rossetti, 2014; Cianca \& Marquezine, 2014; Rech \& Freitas, 2005), and one of these studies had teachers and staff as participants (Barreto \& Mettrau, 2010). The surveys that were performed with college students (Bain et al., 2006; Ramalho et al., 2014; Wechsler \& Suarez, 2016), that is, possible future teachers, did not get different results from researches with teachers. Such studies shown that college students were unaware of the issue HS/GD and that myths / SR are present in their speeches.

Teachers and other professionals need training to know the myths / SR, so it can contribute to avoiding the spreading of these myths is a recurring theme among studies. This issue resounds with researchers Bain et al. (2006) state, that by examining the SR on HS/GD based on empirical evidence, facilitates the development of more relevant 
practices that reduce the misperceptions, harmful and stigmatization effects that permeate the phenomenon.

It should be clarified that the SR found in the analyzed articles may or may not correspond to myths discussed in the literature. Myths, by themselves, carry the idea of the misconceptions about HS/GD, however the SR may correspond to correct ideas or not. Barreto and Mettrau (2010) determine the presence of SR on the conceptualization and characterization of students with HS/GD, public policy and legal support, the teacher's role and continuing education and assistance programs. The HS/GD phenomenon is socially constructed and may be interfering with myths and beliefs of the culture of each location (Güçyeter et al., 2017). Similarly, the SRs are also built in social, through everyday communication, which are compared to the myths (Moscovici, 1982).

The studies performed in England, France and Turkey, besides a study in Brazil, used a large number of participants, being respectively 285, 116, 523 and 170; which brings greater consistency of the presented results (Bain et al., 2006; Kaya et al., 2015; Tavani et al., 2009; Wechsler \& Suarez, 2016). The three international studies used the method of comparison between two groups (Bain et al., 2006; Kaya et al., 2015; Tavani et al., 2009). The three remaining studies also made a comparison between two groups within the participants, but with a lesser number of respondents (Azevedo \& Mettrau, 2010; Barreto \& Mettrau, 2010).

Due to educational issues, it was defined for this study the use of the nomenclature myths/SR, since most articles used either of the expressions. However, this research suggests a contribution: the use of TSR as a guiding tool for future scientific productions researching people's view about HS/GD, as some international researchers have already done (Bain et al., 2006; Kaya et al., 2015; Tavani et al., 2009) as well as some Brazilian researchers (Barreto \& Mettrau, 2010; C. P. M. F. Barreto, 2008). This suggestion of using the TSR can potentially contribute to the homogeneity of the theories in the area of HS/GD, since this theory contributes to the research of the socially constructed phenomenon.

\section{Final considerations}

Overall, the analysis of these studies made it possible to gather the scientific information about the myths/SR about HS/GD, realizes the little production on the subject 
and suggests a unified term for "what people think about HS/GD". The scientific community needs to realize the extreme importance of standardizing the concepts within the HS/GD area as a way to help this population, even considering that there are cultural differences on the HS/GD phenomena, such inconsistency in theoretical definitions does not contribute to the field development of the area.

One of the limiting factors of this study may have been the limited number of queries databases- Scielo, Pepsic, BVS Psi, PubMed, Redalyc and scholar Google - these were chosen by the fact the articles are available for free. Thus, it is suggested that future researches are extended to other databases, so that more studies on the subject can be identified. The lack of consensus on the concepts involving the theme myths/SR and HS/GD has made difficult the used descriptors, which may have contributed to the reduced number of articles found in the above-mentioned databases. Finally, although the above limitations, this article has achieved its goal to synthesize the available information on the theme, besides to highlight that the surveyed area needs a significant increase in the scientific production.

\section{Referências}

Alencar, E. M. L. S., \& Fleith, D. S. (2001). Superdotados: determinantes, educação e ajustamento. São Paulo: EPU.

Antipoff, C. A., \& Campos, R. H. d. F. (2010). Superdotação e seus mitos. Psicologia Escolar e Educacional, 14(2), 301-309. doi: 10.1590/S1413-85572010000200012

Azevedo, S. M. L. d., \& Mettrau, M. B. (2010). Altas habilidades/superdotação: mitos e dilemas docentes na indicação para o atendimento. Psicologia: ciência e profissão, 30(1), 32-45. doi: INEXISTENTE

Bahiense, T. R. S., \& Rossetti, C. B. (2014). Altas habilidades/superdotação no contexto escolar: percepções de professores e prática docente. Revista Brasileira de Educação Especial, 20(2), 195-208. doi: 10.1590/S1413-65382014000200004

Bain, S. K., Choate, S. M., \& Bliss, S. L. (2006). Perceptions of developmental, social, and emotional issues in giftedness: Are they realistic? Roeper Review, 29(1), 41-48. doi: $10.1080 / 02783190609554383$ 
Barreto, C. P. M. F., \& Mettrau, M. B. (2010). Altas habilidades e o desafio do atendimento. Estudos Interdisciplinares em Psicologia, 1(1), 66-79. doi: INEXISTENTE

Barreto, C. P. M. F. (2008). Altas Habilidades / Superdotação: Representações Sociais dos professores do colégio Pedro II. (Mestrado), Universidade Salgado de Oliveira, Niterói.

Brasil. (1995). Diretrizes gerais para o atendimento educacional aos alunos portadores de altas habilidades: superdotação e talentos. Brasília: Ministério da Educação e do Desporto / Secretaria de Educação Especial.

Brasil. (2007). Educação do aluno com altas habilidades/superdotação: Legislação e políticas educacionais para a inclusão. Brasília: Ministério da Educação - Secretaria de Educação Especial.

Chacon, M. C. M., \& Martins, B. A. (2014). A produção-científica do Brasil na área das altas habilidades/superdotação no período de 1987 a 2011. Revista Educação Especial, 27(49), 353-372. doi: 10.5902/1984686X9204

Cianca, F. S. C., \& Marquezine, M. C. (2014). A percepção dos coordenadores de licenciaturas da UEL sobre altas habilidades/superdotação. Revista Brasileira de Educação Especial, 20(4), 591-604. doi: 10.1590/S1413-65382014000400010

Delou, C. M. C. (2007). Educação do aluno com altas habilidades/superdotação: legislação e políticas educacionais para a inclusão. In D. d. S. Fleith (Ed.), A Construção de Práticas Educacionais para Alunos com Altas Habilidades / Superdotação (pp. 25-40). Brasília: MEC

França-Freitas, M. L. P. d., Prette, A. D., \& Prette, Z. A. P. D. (2017). Habilidades Sociais e Bem-Estar Subjetivo de Crianças Dotadas e Talentosas. Psico-USF, 22(1), 1-12. doi: $10.1590 / 1413-82712017220101$

García-Barrera, A., \& de la Flor, P. (2016). Percepción del profesorado español sobre el alumnado con altas capacidades. Estudios pedagógicos (Valdivia), 42(2), 129-149. doi: 10.4067/S0718-07052016000200008

Güçyeter, Ş., Kanl1, E., Özyaprak, M., \& Leana-Taşcılar, M. Z. (2017). Serving gifted children in developmental and threshold countries - Turkey. Cogent Education, 4(1), 1332839. doi: 10.1080/2331186X.2017.1332839 
Jodelet, D. (2001). Representações sociais: um domínio em expansão. In D. Jodelet (Ed.), As representações sociais (pp. 17-44). Rio de Janeiro: EdUERJ

Kaya, F., Ogurlu, Ü., Tasdemir, B., \& Toprak, Y. (2015). Social Representions of giftedness in Turkey. Journal of theory and practice in education, 11(2), 742-765. doi: INEXISTENTE

Martins, B. A., Pedro, K. M., \& Ogeda, C. M. M. (2016). Altas habilidades/superdotação: o que dizem as pesquisas sobre estas crianças invisíveis? Psicologia Escolar e Educacional, 20(3), 561-568. doi: 10.1590/2175-3539201502031046

MEC. (2006). Saberes e práticas da inclusão. Desenvolvendo competências para o atendimento às necessidades educacionais de alunos com altas habilidades/superdotação. Brasília: MEC.

Moscovici, S. (1982). On social representation. . In J. P. Forgas (Ed.), Social Cognition (pp. 181-209). Londres: Academic Press

Nakano, T. C., \& Siqueira, L. G. G. (2012). Revisão de publicações brasileiras sobre superdotação. Revista Educação Especial, 25(43), 249-266. doi: 10.5902/1984686X

Pederro, M. d. F. P., Brero, D. R. B. A., Silva, R. V., Cunha, A. M. T., Gonçalves, L. F., Campos, É. B. V., \& Neme, C. M. B. (2017). Revisão das produções científcas sobre altas habilidades/superdotação no Brasil no período de 2011 a 2015. Revista Educação Especial, 30(58), 499-514. doi: 10.5902/1984686X

Pérez, S. G. P. B. (2011). O culto aos mitos sobre as altas habilidades/superdotação? Psicologia Argumento, 29(67), 513-531. doi: INEXISTENTE

Polli, G. M., \& Camargo, B. V. (2015). Social Representations of the Environment in Press Media. Paidéia (Ribeirão Preto), 25(61), 261-269. doi: 10.1590/198243272561201514

Polli, G. M., Silva, J. C. C., Pereira, M. G., Reis, R. A., Peruci, T. T., Gelinski, E. M. M., \& Gebara, T. S. S. (2018). Social representations of anorexia among university students and risk factors: possible relations. Psico PUCRS, 49(1), 12-20. doi: $10.15448 / 1980-8623.2018 .1 .25251$

Ramalho, J. V. d. A., Silveira, D. N., Barros, W. S., \& Brum, R. d. S. (2014). A carência de formação sobre a superdotação nas licenciaturas da ufpel: um estudo de caso. 
Revista Brasileira de Educação Especial, 20(2), 235-248. doi: 10.1590/S141365382014000200007

Rech, A. J. D., \& Freitas, S. N. (2005). Uma análise dos mitos que envolvem os alunos com altas habilidades: a realidade de uma escola de Santa Maria/RS. Revista Brasileira de Educação Especial, 11(2), 295-314. doi: 10.1590/S1413-65382005000200009

Renzulli, J. S. (1986). The three-ring conception of giftedness: A developmental model for creative productivity. In R. J. Sternberg \& J. E. Davidson (Eds.), Conception of giftedness (pp. 53-92). New York: Cambridge University Press

Sabatella, M. L. P. (2013). Talento e Superdotação, Problema ou Solução? Curitiba: InterSaberes.

Tavani, J. L., Zenasni, F., \& Pereira-Fradin, M. (2009). Social representation of gifted children: a preliminar study in France. Gifted and Talented International, 24(2), 6170. doi: INEXISTENTE

Wechsler, S. M., \& Suarez, J. T. (2016). Percepção de professores em cursos de formação sobre talentos/superdotação. Revista de Psicología (PUCP), 34(1), 39-60. doi: 10.18800/psico.201601.002

WHO. (2002). Community participation in local health and sustainable development. Aproches and techniques. Copenhagen: WHO.

Winner, E. (1996). Crianças sobredotadas, mitos e realidades. Lisboa: Instituto Piaget. 